\title{
Regulatory Interactions Between Quorum-Sensing, Auxin, Cytokinin, and the Hrp Regulon in Relation to Gall Formation and Epiphytic Fitness of Pantoea agglomerans pv. gypsophilae
}

\author{
Laura Chalupowicz,, ${ }^{1,2}$ Isaac Barash, ${ }^{2}$ Mary Panijel, ${ }^{2}$ Guido Sessa, ${ }^{2}$ and Shulamit Manulis-Sasson ${ }^{1}$ \\ ${ }^{1}$ Department of Plant Pathology and Weed Research, ARO, the Volcani Center, Bet Dagan, 50250, Israel; ${ }^{2}$ Department \\ of Plant Sciences, Tel-Aviv University, Tel-Aviv 69978, Israel
}

Submitted 1 January 2009. Accepted 9 March 2009.

\begin{abstract}
Gall formation by Pantoea agglomerans pv. gypsophilae is controlled by hrp/hrc genes, phytohormones, and the quorum-sensing $(\mathrm{QS})$ regulatory system. The interactions between these three components were investigated. Disruption of the QS genes pagI and pagR and deletion of both substantially reduced the transcription levels of the $h r p$ regulatory genes $h r p X Y, h r p S$, and $h r p L$, as determined by quantitative reverse-transcriptase polymerase chain reaction. Expression of $h r p L$ in planta was inhibited by addition of 20 $\mu M$ or higher concentrations of the QS signal $\mathrm{C}_{4}$-HSL. The pagR and $h r p L$ mutants caused an equivalent reduction of 1.3 orders in bacterial multiplication on bean leaves, suggesting possible mediation of the QS effect on epiphytic fitness of $P$. agglomerans pv. gypsophilae by the hrp regulatory system. indole-3-acetic acid (IAA) and cytokinin significantly affected the expression of the QS and $h r p$ regulatory genes. Transcription of pagI, pagR, hrpL, and $h r p S$ in planta was substantially reduced in $i a a H$ mutant (disrupted in IAA biosynthesis via the indole-3-acetamide pathway) and etz mutant (disrupted in cytokinin biosynthesis). In contrast, the ipdC mutant (disrupted in IAA biosynthesis via the indole-3-pyruvate pathway) substantially increased expression of pagI, pagR, hrpL, and hrpS. Results presented suggest the involvement of IAA and cytokinins in regulation of the QS system and $h r p$ regulatory genes.
\end{abstract}

Pantoea agglomerans (previously Erwinia herbicola) has been transformed from a commensal and epiphytic bacterium associated with many plants into a host-specific tumorigenic pathogen, by acquiring a plasmid-borne pathogenicity island (PAI) (Barash and Manulis-Sasson 2007; Manulis and Barash 2003). Unique features of this PAI that are relevant to virulence include the presence of a functional $h r p / h r c$ gene cluster encoding the type III secretion system (T3SS), a regulatory cascade controlling the Hrp regulon, genes encoding type III effectors, and a cluster of genes responsible for biosynthesis of indole-3-acetic acid (IAA) and cytokinin (CK) (Barash and Manulis-Sasson 2007). It has been demonstrated that gall formation by the two related pathovars, $P$. agglomerans pv. gypsophilae, pathogenic on gypsophila, and $P$. agglomerans $\mathrm{pv}$. betae, pathogenic on gypsophila and beet, is Hrp dependent (i.e., mutations in the hrp/hrc gene cluster completely abolished

Corresponding author: S. Manulis-Sasson;

E-mail: shulam@volcani.agri.gov.il gall formation) (Mor et al. 2001; Nizan et al. 1997; NizanKoren et al. 2003). The regulatory cascade that activates the Hrp regulon in P. agglomerans pv. gypsophilae 824-1 (824-1) has been characterized (Nizan-Koren et al. 2003); it contains an $h r p X Y$ operon encoding a two-component system (i.e., $h r p S$ encoding a transcriptional factor of the NtrC family and $h r p L$ encoding an alternative sigma factor). The following signal transduction model was suggested: phosphorylated HrpY activates $h r p S$, HrpS activates $h r p L$, and $\operatorname{HrpL}$ activates genes containing the "hrp box" promoter. The $h r p$ box is common to all the genes controlled by the Hrp regulon, which is essentially composed of genes encoding the T3SS and type III effectors (Alfano and Collmer 2004). Binding of HrpL protein to the hrp box promoter in $P$. agglomerans pv. gypsophilae and the precise relationship between its base composition and promoter activity have been described (Nissan et al. 2005).

The development of a plant tumor is characterized by increases in the number (hyperplasia) and size (hypertrophy) of cells, which are attributed to overproduction of IAA and CK (Morris 1986). It has been shown that gall-forming P. agglomerans strains possess two major metabolic pathways for IAA biosynthesis, the indole-3-acetamide (IAM) and the indole-3pyruvate (IPyA) routes, in contrast to nonpathogenic strains, which carry only the IPyA pathway (Manulis et al. 1991). Inactivation of the plasmid-borne IAM pathway was achieved by mutagenesis of its genes encoding for tryptophan-2-monooxygenase (iaaM) or IAM hydrolase (iaaH) (Clark et al. 1993), whereas the chromosomal IPyA pathway was inactivated by mutagenesis of its key gene, ipdC, encoding for IPyA decarboxylase (Brandl and Lindow 1996; Manulis et al. 1998). The key gene for CK biosynthesis is isopentenyl transferase (ipt) (Morris 1986). A marker exchange mutant of the plasmidborne ipt homolog (etz) was generated in P. agglomerans pv. gypsophilae and it prevented CK production (Lichter et al. 1995). Inactivation of either the IAM pathway or CK biosynthesis caused 40 to $50 \%$ reduction in gall size, whereas simultaneous inactivation of the two pathways for IAA and CK biosynthesis in $P$. agglomerans pv. gypsophilae also reduced gall size by approximately $50 \%$ but did not prevent gall formation (Manulis et al. 1998). It is noteworthy that a differential contribution of the IAM and IPyA pathways for IAA biosynthesis to pathogenicity and epiphytic fitness, respectively, was observed in P. agglomerans pv. gypsophilae (Manulis et al. 1998). Thus, inactivation of the IAM pathway substantially reduced gall formation in gypsophila cuttings but not epiphytic fitness on bean or gypsophila leaves, whereas inactivation of the IPyA 
pathway adversely affected epiphytic fitness but not pathogenicity. Taken together, it can be concluded that IAA and CK secreted by the pathogen may play a significant but secondary role in gall development, unlike $h r p / h r c$ genes that perform a primary function (Barash and Manulis-Sasson 2007). Because both IAA and $\mathrm{CK}$ are required for stimulating hyperplasia and hypertrophy involved in gall formation (Morris 1986), it was hypothesized that type III effector proteins injected via the T3SS can manipulate the plant to produce the necessary IAA and CK for tumorigenesis (Barash and Manulis-Sasson 2007).

A quorum-sensing $(\mathrm{QS})$ regulatory system has recently been characterized in $P$. agglomerans pv. gypsophilae 834-1 (Chalupowicz et al. 2008): P. agglomerans pv. gypsophilae produces $\mathrm{N}$-butanoyl-L-homoserine lactone $\left(\mathrm{C}_{4}-\mathrm{HSL}\right)$ as a major and $N$-hexanoyl-L-homoserine lactone $\left(\mathrm{C}_{6}\right.$-HSL) as a minor QS signal. Homologs of luxI and luxR regulatory genes, pagI (encoding $\mathrm{C}_{4}$-HSL synthase) and pagR (encoding the transcriptional regulator), were characterized and shown to be convergently transcribed. The deduced PagI (23.8 kDa) and PagR (26.9 $\mathrm{kDa}$ ) as well as the QS signals showed striking similarity to those in Serratia sp. ATCC 39006 (Thomson et al. 2000). The

Table 1. Relevant primers used for quantitative reverse-transcriptase polymerase chain reaction analysis

\begin{tabular}{lll}
\hline Name & \multicolumn{1}{c}{ Sequence $\left(\mathbf{5}^{\prime} \rightarrow \mathbf{3}^{\prime}\right)$} & $\begin{array}{c}\text { Expressed } \\
\text { gene }\end{array}$ \\
\hline gyrBRTFow & GGTGAAAGTGCCGGATCCTAA & gyrB \\
gyrBRTRev & TGCTGCTCAACCGCTGTTT & $\ldots$ \\
hrpLRTFow & GGTACAGATGACCTGGCTGGAA & hrpL \\
hrpLRTRev & CCAAAAACCCACGTCTCTGG & $\ldots$ \\
hrpSRTFow & ATCCAGTTACAGCCTCTC & hrpS \\
hrpSRTRev & CTAATCCCAACACAAATCG & $\ldots$ \\
hrpXRTFow & TGCCATCTACCTGATTGAC & hrpX \\
hrpXRTRev & CCGTTCTGCTCTCTTACC & $\ldots$ \\
hrpYRTFow & TGAGCGAAGCGGGAAATG & hrpY \\
hrpYRTRev & GGTATTGCGAGTGAATCTGG & $\ldots$ \\
RFow & TACGCCGAAGTTGCGGTCAT & pagR \\
RRev & ACCGCATGTGTGGCGTT & $\ldots$ \\
IFow & ACAGCCGGCTAATCTCACAACA & pagI \\
IRev & TGGGCATGCATAACGGGAAGTT & $\ldots$ \\
iaaFow & TTTCCGGATCCAGGCATTGT & iaaH \\
iaaRev & AATAAAGCCCGCCAGCCATTCT & $\ldots$ \\
etzFow & GAGAGGTCTGGCTGATGGG & etz \\
etzRev & CTTCTGGCAAGGATAGCACTC & $\ldots$ \\
rsmAFow & TCGTCGAGTTGGTGAAACCCTCAT & rsmA \\
rsmARev & ATCTCTTCGCGATGCACAGACACT & $\ldots$ \\
\hline
\end{tabular}

presence of the QS signals and the regulatory genes in pathogenic as well as in nonpathogenic strains of P. agglomerans, which lack the pPATH plasmid, suggested that they do not reside on the pathogenicity plasmid and are quite likely chromosomal (Chalupowicz et al. 2008). Disruption of either pagR or pagI or both genes simultaneously in strain $824-1$ reduced gall size in gypsophila cuttings by 50 to $55 \%$ when plants were inoculated with $10^{6} \mathrm{CFU} / \mathrm{ml}$. Higher reduction in gall size (70 to $90 \%$ ) was achieved by overexpression of pagI or addition of exogenous $\mathrm{C}_{4}$-HSL (Chalupowicz et al. 2008).

The reduction of gall development in QS mutants could be attributed to a positive effect of this global regulatory system on the Hrp regulon. Alternatively, it could be caused by a negative effect of QS on biosynthesis of IAA and CK that leads to reduction in gall size. It is noteworthy that a reduction of approximately $50 \%$ was reported for pagI or pagR mutants (Chalupowicz et al. 2008), which is similar to that obtained by inactivation of IAA and CK biosynthesis pathways (Manulis et al. 1998). Initial support for the first premise was obtained by monitoring the expression of the $h r p / h r c$ regulatory gene $h r p L$ and the T3SS effector pthG in pagI mutant background using quantitative reverse-transcriptase polymerase chain reaction (qRT-PCR) under in vitro conditions (Chalupowicz et al. 2008). The possibility that the observed reduction in gall size resulted from suppression of IAA or CK biosynthesis through inactivation of the QS system was tested in the present study and was ruled out because QS mutations did not affect the expression of $i a a H$, ipdC, and etz. These preliminary results prompted us to further investigate the regulatory interrelationships among biosynthesis of IAA and CK, QS, and activation of the Hrp regulon under in planta conditions. The present study was undertaken to i) demonstrate the effect of the QS system on expression of the Hrp regulon in planta and ii) elucidate the interactions between biosynthesis of IAA and CK, the QS regulatory system, and expression of the Hrp regulon.

\section{RESULTS}

The $h r p / h r c$ regulatory genes $h r p X Y, h r p S$, and $h r p L$ are controlled by the QS system in planta.

It has been previously reported that disruption of pagI in 824-1 significantly reduced the transcript level of the regulatory gene $h r p L$ in cultures grown on minimal A medium (Chalupowicz et al. 2008). To further corroborate this observation, the expressions of the other Hrp regulatory genes, namely,

Table 2. Bacterial strains and plasmids used in this study

\begin{tabular}{|c|c|c|}
\hline Strains, plasmids & Relevant characteristics $^{\mathrm{a}}$ & Reference or source \\
\hline \multicolumn{3}{|l|}{ Strains } \\
\hline \multicolumn{3}{|l|}{ Escherichia coli } \\
\hline DH5 $\alpha$ & lacZ $\Delta \mathrm{M} 15 \Delta$ (lacZYA-argF) U169 gyrA96 & Invitrogen ${ }^{\mathrm{b}}$ \\
\hline \multicolumn{3}{|c|}{ Pantoea agglomerans pv. gypsophilae } \\
\hline $824-1$ & Pathogenic strain with spontaneous Rif ${ }^{\mathrm{r}}$, gypsophila pathovar & Manulis et al. 1991 \\
\hline MxI & $\operatorname{Rif}^{\mathrm{r}}, \mathrm{Spec}^{\mathrm{r}}, 824-1$ marker exchange mutant with $\Omega$ cartridge in pagI $\left(\mathrm{AHL}^{-}\right)$ & Chalupowicz et al. 2008 \\
\hline MxR & $\operatorname{Rif}^{\mathrm{r}}, \mathrm{Km}^{\mathrm{r}}, 824-1$ marker exchange mutant with kanamycin cassette in $p a g R$ & Chalupowicz et al. 2008 \\
\hline $\mathrm{Mx} \Delta \mathrm{IR}$ & $\operatorname{Rif}^{\mathrm{r}}, \mathrm{Km}^{\mathrm{r}}, 824-1$ marker exchange with double deletion in pagI and $p a g R$ & Chalupowicz et al. 2008 \\
\hline $\mathrm{MxL}$ & $\operatorname{Rif}^{\mathrm{r}}$, Spec ${ }^{\mathrm{r}}, 824-1$ marker exchange mutant of Tn3-Spice in $h r p L$ & Nizan-Koren et al. 2003 \\
\hline $\mathrm{MxJ}$ & $\operatorname{Rif}^{\mathrm{r}}$, Spec ${ }^{\mathrm{r}}, 824-1$ marker exchange mutant of Tn3-Spice in $h r p J$ & Nizan-Koren et al. 2003 \\
\hline MxIaaH & $\mathrm{Rif}^{\mathrm{r}}, \mathrm{Km}^{\mathrm{r}}, 824-1$ marker exchange mutant in iaaH (Ehg824-1MX54) & Manulis et al. 1998 \\
\hline MxEtz & $\operatorname{Rif}^{\mathrm{r}}, \mathrm{Km}^{\mathrm{r}}, 824-1$ marker exchange mutant in etz (Ehg824-1MX37) & Manulis et al. 1998 \\
\hline MxIpdC & Rif $^{\mathrm{r}}$, Spec ${ }^{\mathrm{r}}, 824-1$ marker exchange mutant in ipdC (Ehg824-1MX119) & Manulis et al. 1998 \\
\hline PD713 & Pathogenic strain on gypsophila & Manulis et al. 1991 \\
\hline \multicolumn{3}{|l|}{ Plasmids } \\
\hline pWM1029 & $\mathrm{Km}^{\mathrm{r}}$, Spec ${ }^{\mathrm{r}}$, broad-host-range plasmid for green fluorescent protein expression & Cooley et al. 2003 \\
\hline pAKC891 & Spec $^{\mathrm{r}}, 3.0-\mathrm{kb}$ EcoRI-SacI fragment containing $r s m A_{\text {Ehg }}$ in pCL1921 & Ma et al. 2001 \\
\hline pCLrsmA & Spec $^{\mathrm{r}}$, 3.0-kb SacI fragment containing $r s m A_{\text {Pag }}$ in pCL1920 & This study \\
\hline
\end{tabular}

\footnotetext{
${ }^{\mathrm{a}} \mathrm{Rif}^{\mathrm{r}}, \mathrm{Spec}^{\mathrm{r}}$, and $\mathrm{Km}^{\mathrm{r}}$ indicate resistance to rifampicin, spectinomycin, and kanamycin, respectively.

${ }^{\mathrm{b}}$ Invitrogen, San Diego, CA, U.S.A.
} 
$h r p X Y$ and $h r p S$, as well as $h r p L$, were measured by qRT-PCR in planta. The PCR primers employed for amplification of each gene are given in Table 1. Gypsophila cuttings were dip inoculated with cell suspensions $\left(10^{6}\right.$ cells $\left./ \mathrm{ml}\right)$ of $824-1$ and its QS mutant strains MxI, MxR, and Mx $\Delta I R$ (Table 2). After incubation for $16 \mathrm{~h}$ at $25^{\circ} \mathrm{C}$, the total RNA was extracted from the inoculated plants and the levels of mRNA were determined as described below. Inactivation of pagI and pagR and simultaneous deletion of the two genes (pagI/R) reduced the transcript levels of $h r p X Y$ by 3.6-, 2.2-, and 3.3-fold, respectively; those of $h r p S$ by 1.6-, 4.5-, and 5.3-fold, respectively; and those of hrpL by 5.5-, 9.0-, and 25-fold, respectively, compared with those in the wild-type strain $824-1$ (Fig. 1). These results indicate that each member of the Hrp regulatory system is under the control of QS and that both functional pagI and functional $p a g R$ are required for activating the cascade of these regulatory genes.

High concentrations of $\mathrm{C}_{4}$-HSL were previously shown to reduce gall development (Chalupowicz et al. 2008); therefore, we further investigated whether expression of $h r p L$ was affected by addition of $\mathrm{C}_{4}$-HSL. Gypsophila cuttings were infected by cell suspension $\left(10^{6}\right.$ cells $\left./ \mathrm{ml}\right)$ of the wild-type strain $824-1$ in the absence and presence of $\mathrm{C}_{4}$-HSL at 2, 20, and $200 \mu \mathrm{M}$, and total RNA was extracted and evaluated for $h r p L$ expression by qRT-PCR, as described above. The results (Fig. 2) revealed that the transcript level of $h r p L$ was slightly higher after addition of $2 \mu \mathrm{M} \mathrm{C}_{4}$-HSL than that produced by $824-1$. However, substantial reductions of two- and fourfold were observed in response to 20 and $200 \mu \mathrm{M}$ of $\mathrm{C}_{4}$-HSL, respectively, compared with the wild-type control strain.

\section{Colonization of $P$. agglomerans pv. gypsophilae in planta is dependent on functional QS system and inhibited by high levels of $\mathrm{C}_{4}$-HSL.}

The effect of the QS system on colonization of gypsophila cuttings by $P$. agglomerans pv. gypsophilae was assessed during early stages of infection. The multiplication of the QS mutants $p a g I^{-}(\mathrm{MxI})$ and pag $\Delta I R^{-}(\mathrm{Mx} \Delta \mathrm{IR})$ was compared with that of the wild-type strain (824-1) and of an $\mathrm{hrpJ}^{-}(\mathrm{MxJ}) \mathrm{mu}-$ tant deficient in functional T3SS (Nizan-Koren et al. 2003).

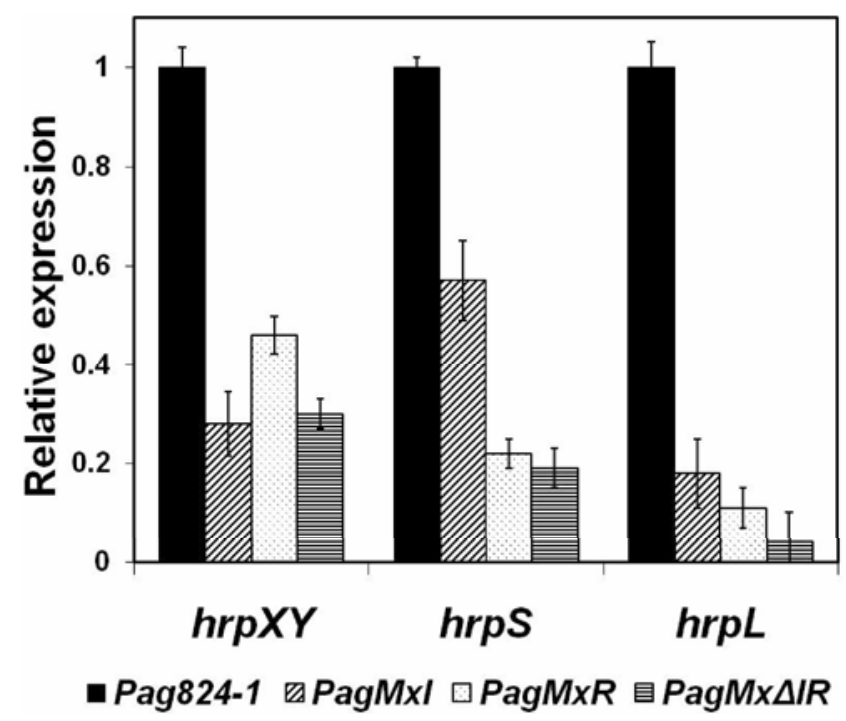

Fig. 1. Transcript levels of $h r p X Y, h r p S$ and $h r p L$ in the wild-type Pantoea agglomerans pv. gypsophilae 824-1 (Pag824-1) and quorum-sensing mutants (PagMxI, PagMxR, and PagMx $\mathrm{IIR}$ ) in planta. Template cDNAs were generated from total RNA extracts of infected gypsophila cuttings $16 \mathrm{~h}$ after inoculation. Gene expression was normalized with $\operatorname{gyr} B$ used as an endogenous reference and Pag824-1 as the control. Results represent three different experiments with standard deviation.
Gypsophila cuttings were inoculated with $10^{6}$ cells $/ \mathrm{ml}$ and the bacterial population was monitored after $1,2,3$, and 4 days as described below. The populations of $824-1$ and $h r p J$ mutant in gypsophila cuttings increased by approximately two orders of magnitude during the initial $24 \mathrm{~h}$, compared with increases by only one order of magnitude in the populations of pagI and Pag $\Delta$ IR mutants (Fig. 3A). After 2, 3, and 4 days, the populations of the two QS mutants as well as that of hrpJ mutant remained similarly smaller (by 2.0 to 2.67 orders) than that of the wild type (Fig. 3A). These results could imply that the QS system might affect growth earlier than the Hrp system, and during the period in which the increased multiplication appeared to be Hrp independent (Valinsky et al. 2002). Addition of 200 $\mu \mathrm{M} \mathrm{C}_{4}$-HSL to $824-1$ inhibited growth by approximately one order after 4 days compared with the wild type without addition of $\mathrm{C}_{4}$-HSL, which correlates with the effect of excessive signal on $h r p L$ expression (Fig. 2).

To further support the above result, gypsophila cuttings were inoculated with 824-1 and with $\mathrm{MxI}$ and $\mathrm{Mx} \Delta \mathrm{IR}$ mutants into which a plasmid for green fluorescent protein (GFP) expression (pWM1029) was introduced, as described below. Confocal images of longitudinal sections taken 6 days after inoculation with GFP-tagged 824-1 revealed the presence of abundant bacterial aggregates colonizing the xylem and adjacent parenchymal cells, in contrast to the two QS mutants, which exhibited only scattered bacterial aggregates (Fig. 3B).

\section{Effects of pagI and pagR on epiphytic fitness.}

It is now well established that the QS system regulates epiphytic fitness in Pseudomonas syringae (Quinones et al. 2005). Previous (Chalupowicz et al. 2008) and present results suggest that the QS system in 824-1 governs the Hrp regulon. The following experiment was intended to determine whether the QS affected epiphytic fitness of Pantoea agglomerans pv. gypsophilae and whether this effect could be attributed to its interaction with the Hrp regulon. To test this hypothesis, we investigated the effects of mutants disrupted in the QS system (i.e., pagI $I^{-}$and $\left.p a g R^{-}\right)$and in the T3SS system $\left(h r p L^{-}\right)$on epiphytic fitness of 824-1. Bean leaves were inoculated by dipping them in bacterial suspension $\left(10^{6}\right.$ cells $\left./ \mathrm{ml}\right)$ and the plants were subjected to moist followed by dry conditions, as described below. During the first $48 \mathrm{~h}$, under wet conditions, the bacterial populations of the wild-type strain and the mutants increased by approximately two orders of magnitude (Fig. 4). However, after the $48 \mathrm{~h}$ of dry conditions, the populations of $p a g R^{-}$and the

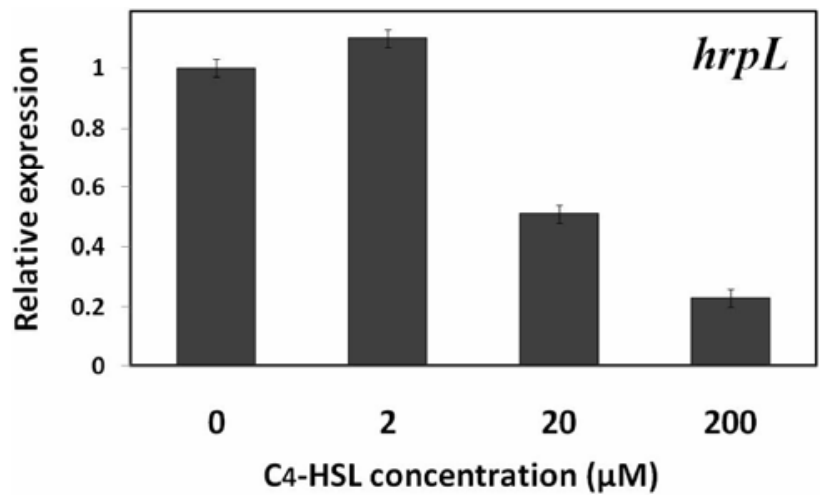

Fig. 2. Expression of $h r p L$ in response to exogenous $\mathrm{C}_{4}$-HSL. The transcript levels of $h r p L$ were examined in Pantoea agglomerans pv. gypsophilae 824-1 (Pag824-1) $16 \mathrm{~h}$ after inoculation of gypsophila cuttings, and in the presence of 2, 20, and $200 \mu \mathrm{M} \mathrm{C}_{4}$-HSL. Relative levels of $h r p L$ were normalized with $g y r B$ used as an internal reference and Pag824-1 without addition of $\mathrm{C}_{4}$-HSL as control. Results represent three different experiments with standard deviation. 
$h r p L^{-}$mutants showed similar reductions of 1.3 orders of magnitude, whereas mutation in pagI caused only a slight decrease, of 0.7 orders. Taken together, these data could suggest that T3SS effectors might contribute to the effect of the QS on epiphytic fitness.

\section{Disruption of biosynthetic pathways for IAA and CK affects the transcription levels of QS and Hrp regulatory genes.}

The interrelationships among biosynthesis of IAA and CK, the QS regulatory system, and activation of the Hrp regulon were studied in planta. As indicated above, two routes for IAA biosynthesis are present in P. agglomerans pv. gypsophilae: the pPATH-borne IAM pathway and the chromosomal IPyA pathway. Mutants in $i a a H$ and $i p d C$ inactivated the IAM and IPyA routes, respectively, whereas a mutant in etz disrupted the biosynthesis of CK (Manulis et al. 1998). Initially, we used a qRT-PCR with primers described in Table 1 to examine the
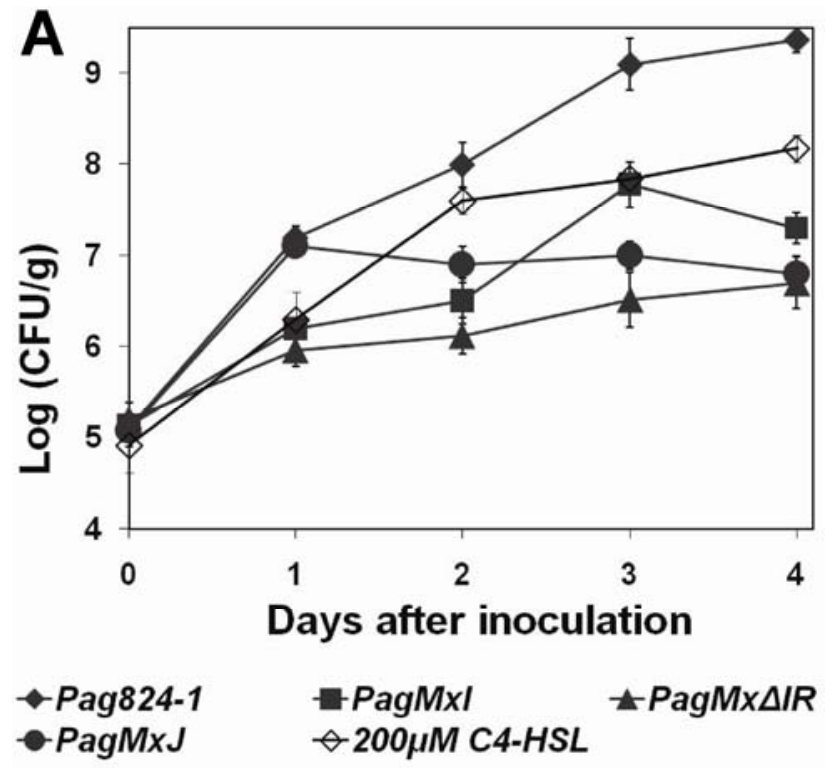

B

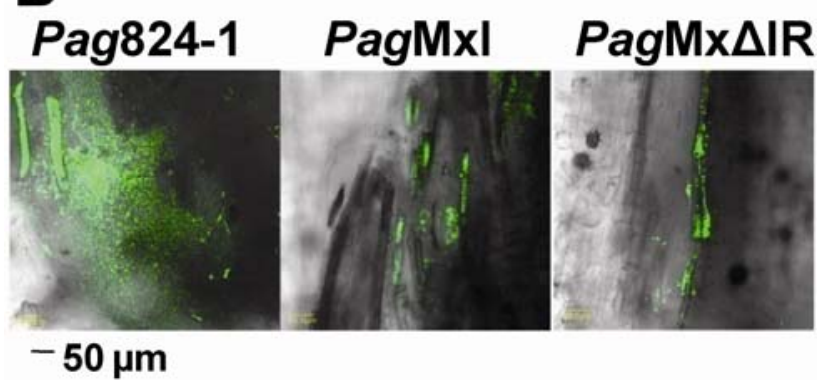

Fig. 3. Effects of quorum-sensing (QS) system on multiplication of Pantoea agglomerans pv. gypsophilae in planta. A, Multiplication of the QS and $h r p J$ mutants compared with the wild type (with and without addition of $\mathrm{C}_{4}$-HSL) in gypsophila cuttings. Cuttings were dipped in the various bacterial suspensions $\left(10^{6} \mathrm{cells} / \mathrm{ml}\right)$ for $45 \mathrm{~min}$ and colonization was determined after 1, 2, 3, and 4 days. P. agglomerans pv. gypsophilae 824-1 (Pag824-1), wild type; PagMxI, a marker exchange mutant in pagI; PagMx $\Delta \mathrm{IR}$, a deleted pagI/R mutant; PagMxJ, a marker exchange mutant in $h r p J$ and addition of $200 \mu \mathrm{M} \mathrm{C}_{4}$-HSL during inoculation with Pag8241. Results presented are averages of three independent experiments with five replicates for each time point. Bars indicate standard deviations. B, Longitudinal section of infected gypsophila cuttings visualized 6 days after inoculation by confocal fluorescent microscopy. Gypsophila cuttings were inoculated by dipping in a solution $\left(10^{6} \mathrm{cells} / \mathrm{ml}\right)$ of Pag824-1, PagMxI, and PagMxuIR harboring the plasmid pWM1029. The images are representative of three independent experiments (Scale bars, $50 \mu \mathrm{m}$ ). possibility that $p a g I$ or $p a g R$ mutants affected the transcription of iaaH, ipdC, and etz, but negative results were obtained (not shown). In contrast, when the effects of iaaH, ipdc, and etz mutants on the transcriptional levels of pagI, pagR, $h r p L$, and hrpS were tested, significant changes were obtained (Fig. 5). Transcription of pagI was reduced by factors of 5.9 and 2.8 in $i a a H$ and $e t z$ mutants, respectively, compared with 824-1 (wild type) but increased 2.8-fold in ipdC mutant; transcription of pagR decreased by factors of 3.3 and 2.9 in iaaH and etz mutants, respectively, but increased 3.4-fold in ipdC mutant; transcription of $h r p L$ was reduced by factors of 3.6 and 3.8 in iaaH and etz mutants, respectively, but increased 3.1-fold in ipdC mutant; transcription of $h r p S$ was reduced by factors of 9.0 and 5.6 in $i a a H$ and $e t z$ mutants, respectively, but increased 3.8-fold in ipdC mutant.

The possibility that these mutants could be complemented by either IAA or CK was tested. Addition of $100 \mu \mathrm{M}$ IAA to the $i a a H$ and ipdC mutants restored the expression of pagI, pagR, $h r p L$, and $h r p S$ to wild-type levels; namely, it increased the expression of these genes in the iaaH mutant and decreased expression of them in the ipdC mutant, respectively. Similarly, addition of $20 \mu \mathrm{M}$ 6-benzylamionpurine (BA) to the etz mutant increased the expression of pagI, pagR, hrpL, and $h r p S$ to wild-type levels (results not shown). The differential effects of the two IAA biosynthetic pathways on the transcription of the QS and Hrp regulatory genes were surprising because they have an identical end product. Moreover, to the best of our knowledge, CK have not previously been reported to affect transcription of bacterial genes. These two intriguing findings are addressed below (Discussion).

The post-transcriptional regulator RsmA has been reported to play a central role in the interaction between the QS systems and virulence (Mole et al. 2007). The possibility that QS affects the expression level of rsmA in 824-1 was tested in pagI and pagR mutants by using PCR primers of $r s m A$ listed in Table 1. No effect of either of the two mutants on rsmA could be detected (results not shown).

\section{DISCUSSION}

The function of genes encoding T3SS and type III effectors is critical for gall formation by $P$. agglomerans pv. gypsophilae and $P$. agglomerans pv. betae (Barash and Manulis-Sasson

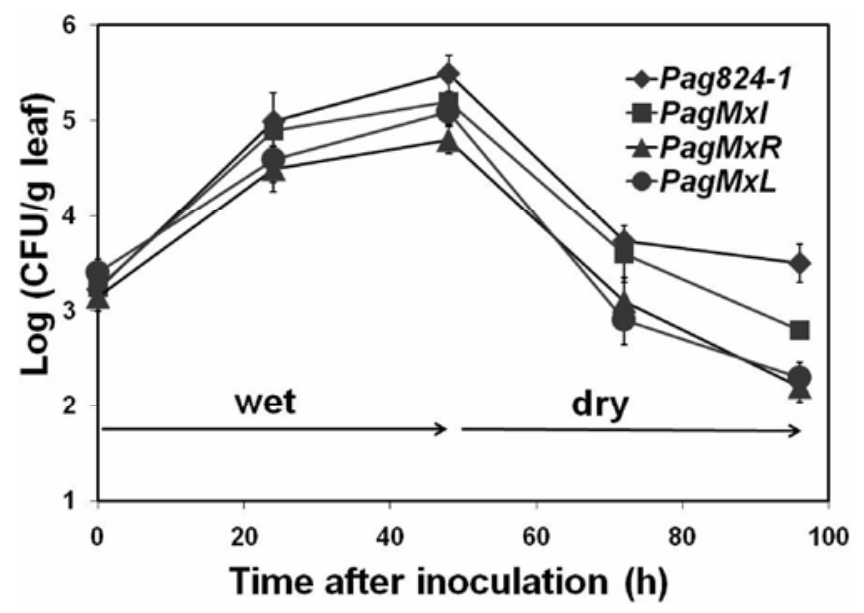

Fig. 4. Population size of Pantoea agglomerans pv. gypsophilae 824-1 (Pag824-1), PagMxI (pagI $\left.{ }^{-}\right)$, PagMxR (pagR ${ }^{-}$, and PagMxL (hrpL $\left.{ }^{-}\right)$on bean leaves. The leaves were kept moist for the first $48 \mathrm{~h}$ after inoculation and then kept dry for the rest of the experiment. The vertical bars represent the standard error of the mean $\log _{10}$-transformed bacterial population size per gram of leaf. 
2007). A linear cascade of regulatory genes ( $h r p X Y$, hrpS, and $h r p L$ ) that activates the Hrp regulon via the hrp box promoter regulates these genes in $P$. agglomerans pv. gypsophilae (Nizan-Koren et al. 2003). We have previously reported that expression of the regulatory gene $h r p L$ and the type III effector $p t h G$ were significantly reduced in a $P$. agglomerans pv. gypsophilae mutant deficient in $\mathrm{C}_{4}$ - $\mathrm{HSL}$ production when grown on minimal medium (Chalupowicz et al. 2008). In the present study, we further corroborate the role of the QS system in controlling the Hrp regulon by studying its effects on $h r p X Y$ and $h r p S$, in addition to $h r p L$, in planta at an inoculum level of $10^{6}$ $\mathrm{CFU} / \mathrm{ml}$. The results presented unequivocally demonstrate that both pagI and pagR are required for full activation of the Hrp regulon (Fig. 1). Information concerning the effect of the QS

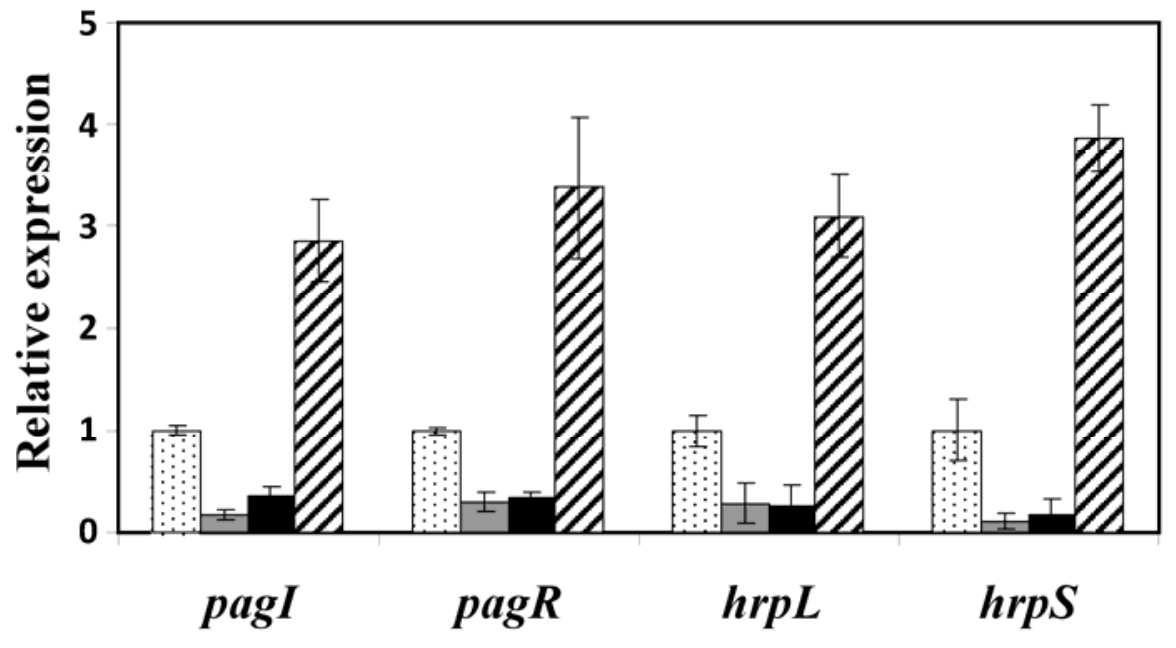

\section{Pag824-1 $\square$ PagMxlaaH $\square$ PagMxEtz a PagMxlpdC}

Fig. 5. Effects of mutations in indole-3-acetic acid (IAA) and cytokinin (CK) biosynthetic genes on pagI, pagR, hrpL, and $h r p S$ transcript levels as determined by quantitative reverse-transcriptase polymerase chain reaction. Pantoea agglomerans pv. gypsophilae MxIaaH (PagMxIaaH), PagMxEtz, and PagMxIpdC are marker exchange mutants in $i a a H$, etz, and ipdC, respectively. cDNA samples were generated from total RNA of Pag824-1 and the various mutants after growth for $16 \mathrm{~h}$ in gypsophila cuttings. Experiments were repeated three times with three replicates for each strain.

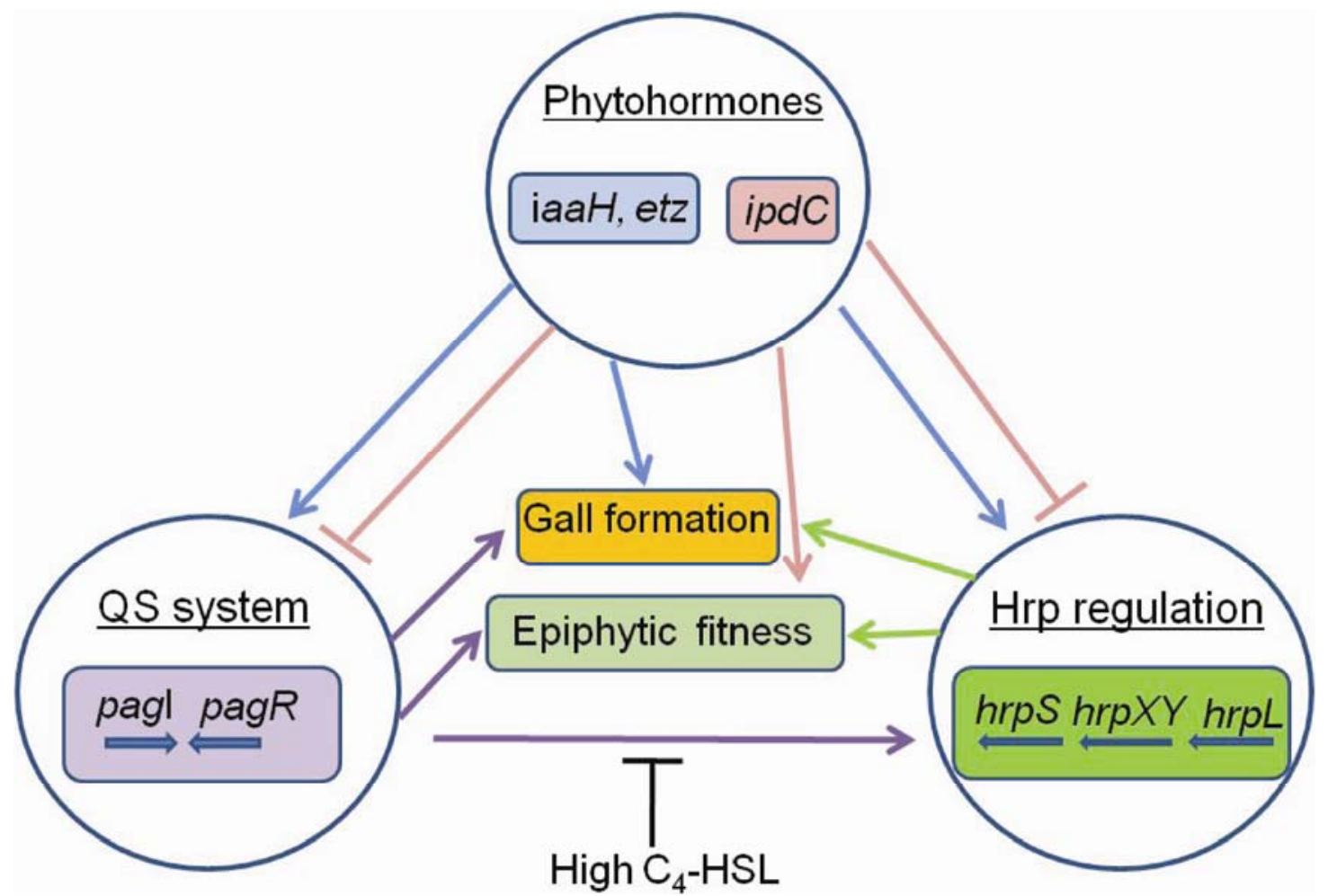

Fig. 6. Relationships among the phytohormones, quorum-sensing (QS) system, and Hrp regulatory genes of Pantoea agglomerans pv. gypsophilae 824-1 and their effects on gall formation and epiphytic fitness. The various components are denoted by circles. Genes and phenotypes are represented by rectangles. Arrows indicate upregulation and barred arrows indicate downregulation. The colors of the arrows correspond to the respective genes. At low inoculum level $\left(10^{6} \mathrm{cells} / \mathrm{ml}\right)$, the biosynthetic pathways for indole-3-acetic acid (IAA) $(\mathrm{iaaH})$ and cytokinin (etz) positively regulated the expression of both the QS (pagI, pagR) and the Hrp regulatory ( $h r p S, h r p X Y, h r p L)$ genes. The IAA pathway (ipdC) negatively regulated the transcription of the Hrp regulon and QS system. The QS system induced expression of the Hrp regulatory genes. High $\mathrm{C}_{4}$-HSL concentrations negatively affected the Hrp regulon. Gall formation and epiphytic fitness were affected by all three systems. 
system on the Hrp regulon is very limited. In the case of Pectobacterium carotovorum subsp. carotovorum, cell-to-cell communication systems are responsible for regulating $h r p L$ and $h r p N$, which are related to the T3SS system, as well as major virulence factors of this pathogen; namely, cell-wall-degrading enzymes (Barnard et al. 2007). In the presence of low concentrations of $\mathrm{C}_{4}-\mathrm{HSL}$, the pagR either directly activates the transcription of $h r p X Y, h r p S$, and $h r p L$ or, alternatively, its effect is mediated by other as-yet-unknown genes. Some support for the direct activation hypothesis could be inferred from the presence of putative lux boxes in the promoters of these genes. The minimal consensus sequence for $l u x$ box according to Whiteley and Greenberg (2001) is [NNCT-(N $\left.\mathrm{N}_{12}\right)$-AGNN]. Sequences that could meet this consensus in the promoter regions of $h r p X Y$ [AACT-CTGTAGATCTGC-AGCC], $h r p S$ [TCCTTACTCGTGGTTC-AGCA], and $h r p L$ [AGCT-GACAGTAT CAGG-AGTG] were identified. Whether these sequences can bind pagR and thereby activate transcription remains to be determined by gel shift experiments. It is also noteworthy that a sequential regulation is responsible for the activation of $h r p L$ (Nizan-Koren et al. 2003). Thus, either activation of $h r p X Y$ expression, in itself, is sufficient for the upregulation of $h r p S$ and $h r p L$ or activation of $h r p S$ stimulates expression of $h r p L$. It is not yet known whether the QS system directly controls each of the three genes or whether only the upstream genes of the cascade are being activated. Another point of interest is that the transcription of $h r p L$ by $p a g R$ could be substantially overridden by addition of excess exogenous $\mathrm{C}_{4}$-HSL (Fig. 2). This finding correlates with a previous observation that gall size on gypsophila cuttings can be reduced by up to $90 \%$ by exposure to exogenous $\mathrm{C}_{4}$-HSL (Chalupowicz et al. 2008). It is possible to hypothesize that the presence of a high concentration of AHL could interfere with the binding of the transcription activator pagR to the DNA as reported by Tsai and Winans for the YenI/yenR system in Yersinia enterocolitica (Von Bodman et al 2008). Another possibility is that the premature activation of the hrp regulatory cascade by a high concentration of the signal caused its suppression by the plant (Chalupowicz et al. 2008).

It is well established that the $h r p / h r c$ gene cluster and type III effectors are necessary for growth of gram-negative phytopathogenic bacteria in planta (Alfano and Collmer 2004; Lindgren 1997). The results presented in Figure 3A imply that under QS conditions (i.e., initial inoculum up to $10^{6} \mathrm{CFU} / \mathrm{ml}$ ) the QS system regulates the bacterial growth rate in planta, most likely through control of the Hrp regulon. This result is in accordance with the demonstration that disruption of the QS genes suppressed expression of the Hrp regulatory genes (Fig. 1) and gall development (Chalupowicz et al. 2008). Interestingly, the colonization by the bacteria in the xylem and adjacent parenchymal cells in gypsophila cuttings appeared in aggregates, which might indicate formation of a biofilm (Koutsoudis et al. 2006). In contrast to the growth of plant-pathogenic bacteria within the plant, which is strongly affected by the action of Hrp genes, bacterial colonization of leaf surfaces employs a range of strategies for growth and survival (Lindow and Brandl 2003). These include, for example, locally increasing the nutrient concentration (Brandl and Lindow 1998), and exopolysaccharide (EPS) production and motility (Quinones et al. 2005). Moreover, bacterial cells form aggregates that endow them with much-enhanced ability to survive periodic desiccation stress and to increase their epiphytic fitness (Monier and Lindow 2003). These colonization strategies are generally controlled by QS and additional global regulatory systems (Quinones et al. 2005; von Bodman et al. 2003). The contribution of hrp/hrc genes to epiphytic fitness of Pseudomonas syringae pv. syringae has been reported previously (Hirano et al. 1999). The results presented in Figure 4 show that the Pantoea agglomerans pv. gypsophilae mutant disrupted in $h r p L$ exhibited a similar reduction in epiphytic fitness to that of P. agglomerans pv. gypsophilae disrupted in pagR, whereas the reduction by pagI mutant was lower. These results suggest that, in addition to the above-mentioned factors, hrp/hrc genes of P. agglomerans pv. gypsophilae contribute to epiphytic fitness of pathogenic bacteria, presumably by internal growth in tissues under the leaf surface.

A most exciting finding of the present study is the regulatory effects of the biosynthetic pathways for IAA and CK on the Hrp regulon and QS system (Fig. 5). Both mutants, in iaaH and in $e t z$, that disrupted the IAM pathways for biosynthesis of IAA and CK, respectively, caused substantial reductions in the expression of the Hrp regulatory genes $h r p L$ and $h r p S$ and the QS genes pagI and pagR compared with the levels in the wildtype control. In contrast, a mutant in ipdC which disrupted the IPyA pathway for IAA caused a substantial increase in the transcription of all these genes (Fig. 5). Auxins and CK are both major classes of plant growth regulators known to be involved in a variety of processes at the whole-plant and cellular levels (Buchanan et al. 2000). The role of IAA as a signaling molecule in bacteria has also been previously demonstrated (Spaepen et al. 2007). It has already been reported that, similarly to our results, disruption of the IAM pathway in $E$. chrysanthemi caused reduced expression levels of genes encoding for Hrp and T3SS effectors such as $h r p L, h r p A$, and $d s p E$, and also of genes encoding endopectate lyases (Yang et al. 2007). However, to the best of our knowledge, there have been no reports on the involvement of $\mathrm{CK}$ in regulation of HSL-mediated QS and Hrp regulatory genes. Moreover, the complementation of the etz mutant by addition of BA strongly suggests that CK may act as signaling molecules in bacteria.

Because the disrupted IAM and IPyA pathways reduced and induced, respectively, expression of the Hrp regulon and QS genes (Fig. 5), it appears that the end product of the IAM pathway may act as a positive signal and that of the IPyA pathway as a negative signal for the Hrp regulon and QS system. The contrasting signaling by the product of these two pathways is difficult to reconcile and is not understood because they both suppose to synthesize IAA. However, it is noteworthy that whereas IAA is the only end product of the IAM hydrolase $(i a a H)$, the IPyA decarboxilase (ipdC) forms indole-3-acetaldehyde, which can be either oxidized to IAA or reduced to indole-3-ethanol, which might be further conjugated or metabolized (Manulis et al. 1991). Whether a different end product from IAA is formed, which could account for the observed difference in signaling of the two pathways, can only be speculated; further studies are required to resolve the above-mentioned questions. It is noteworthy that no effect of ipdC on the QS system and the Hrp regulon has been reported previously. Interestingly, IAA and some synthetic auxins have been reported as signals that upregulate ipdC expression in Azospirillum brasilense (Broek et al. 1999, 2005).

The interactions among IAA and CK, the QS system and the Hrp regulatory genes of 824-1, and their effects on gall formation and epiphytic fitness as presented in this study are summarized in Figure 6. It should be pointed out that the QS is one component of a global regulatory system that includes additional genes such as RsmA, $r s m B$, GacA, and GacS (Brencic and Winans 2005: Lapouge et al. 2008) that have not been addressed in the present study. However, the finding that the pagI and pagR mutants do not exert any effect on transcription of rsmA in P. agglomerans pv. gypsophilae could imply that, unlike Pectobacterium carotovorum subsp. carotovorum (Mole et al. 2007) and similarly to Pseudomonas aeruginosa (Burrowes et al. 2006; Pessi et al. 2001), the QS system does not exert its positive control of the Hrp regulatory genes through RsmA. 
Regardless of the mechanisms involved in signaling of the QS and Hrp regulon by IAA and CK, the present results suggest that production of these phytohormones by Pantoea agglomerans pv. gypsophilae may contribute to optimal expression of the T3SS secretion system and of type III effectors by the pathogen, in addition to their contribution to gall induction.

\section{MATERIALS AND METHODS}

\section{Bacterial strains and growth conditions.}

The bacterial strains used in the present study are listed in Table 2. Wild-type and mutant strains of P. agglomerans pv. gypsophilae were grown in Luria-Bertani (LB) broth or agar at $28^{\circ} \mathrm{C}$, whereas Escherichia coli strains were cultured on the same medium at $37^{\circ} \mathrm{C}$. Antibiotics were used at the following concentrations: kanamycin at $50 \mu \mathrm{g} / \mathrm{ml}$, spectinomycin at 50 $\mu \mathrm{g} / \mathrm{ml}$, and rifampicin at $150 \mu \mathrm{g} / \mathrm{ml}$. All strains were maintained as glycerol stocks at $-80^{\circ} \mathrm{C}$ (Sambrook et al. 1989).

\section{DNA manipulation.}

Isolation of plasmid DNA from E. coli and other DNA manipulations were performed according to standard procedures (Ausubel et al. 1995; Sambrook et al. 1989) or as recommended by the supplier. Synthetic oligonucleotides (Table 1) were synthesized according to the manufacturer's specifications by Sigma-Aldrich (Rehovot, Israel). The E. coli and P. agglomerans strains were transformed by electroporation with a Gene Pulser apparatus (Bio-Rad Laboratories, Hercules, CA, U.S.A.) according to manufacturer's instructions.

To clone the rsmA gene, a fosmid library of 824-1 was screened via colony hybridization with a labeled probe from the plasmid pAKC891 containing the $r s m A$ gene from $P$. agglomerans pv. gypsophilae PD713 (Ma et al. 2001). Positive clones were then digested with $S a c$ I and analyzed by Southern blot hybridization, using the insert of pAKC891 as a probe. The rsmA from $P$. agglomerans pv. gypsophilae was localized in a 3-kb DNA fragment, which was cloned into the SacI site of pCL1920 to produce pCLrsmA. The cloned rsmA with its promoter was sequenced and submitted to the GenBank as accession no. FJ465141.

\section{Plant inoculation.}

Cuttings of Gypsophila paniculata var. Golan (Danziger Ltd., Bet Dagan, Israel) were inoculated according to Lichter and associates (1995). After removal of an approximately 2$\mathrm{mm}$ section from the bottom of the stem, the cuttings (10 for each treatment) were inoculated by dipping into a bacterial suspension of $10^{6}$ cells $/ \mathrm{ml}$ for $16 \mathrm{~h}$ at $25^{\circ} \mathrm{C}$ prior to RNA extraction, or were placed in trays filled with vermiculite for visualization by confocal microscopy 6 days after inoculation. The greenhouse temperature was maintained at 22 to $25^{\circ} \mathrm{C}$ and high humidity was maintained by computer-controlled mist sprinklers (every $20 \mathrm{~min}$ for $10 \mathrm{~s}$ ). Bacterial colonization in gypsophila cuttings was carried out as follows: at various time intervals, five cuttings per treatment were collected and a 10-mm segment was excised from the bottom of each cutting and washed thoroughly with sterile distilled water. Each stem segment was then macerated in $1 \mathrm{ml}$ of 10 $\mathrm{mM}$ phosphate buffer ( $\mathrm{pH}$ 7.0) and serial 10-fold dilutions were plated on LB agar medium containing appropriate antibiotics. The CFU per gram fresh weight was counted and the average of three independent experiments was calculated. Assays with addition of exogenous $\mathrm{C}_{4}$-HSL (Sigma-Aldrich), IAA (Sigma-Aldrich), and BA (Sigma-Aldrich) were performed by dipping gypsophila cuttings into a bacterial suspension of $10^{6}$ cells $/ \mathrm{ml}$ in the presence of 2,20 , or $200 \mu \mathrm{M}$ $\mathrm{C}_{4}$-HSL, $100 \mu \mathrm{M}$ IAA, or $20 \mu \mathrm{M}$ BA.

\section{Epiphytic fitness test.}

Determination of epiphytic fitness was carried out essentially as in previous studies (Lindow 1993; Quinones et al. 2005). Common bean seedlings (Phaseolus vulgaris cv. Sigma) were grown for 2 weeks on a greenhouse bench and the plants were inoculated by immersing the leaves in 1 liter of bacterial suspension in a sterile container. The bacterial suspension was prepared from cells grown on LB selective agar plates incubated overnight at $28^{\circ} \mathrm{C}$, and were suspended in sterile $10 \mathrm{mM}$ potassium phosphate buffer ( $\mathrm{pH}$ 7.0) that was diluted with $1 \mathrm{mM}$ potassium phosphate buffer to a final concentration of $10^{6}$ cells $/ \mathrm{ml}$. Pots, each containing 10 plants, were immersed in a suspension of a given bacterial strain for $1 \mathrm{~min}$. Immediately after inoculation, the pots were covered with plastic bags and held for $48 \mathrm{~h}$ at 26 to $28^{\circ} \mathrm{C}$, so that high relative humidity was maintained. Ten individual leaves from treated plants were harvested at various times and placed individually in large test tubes containing $20 \mathrm{ml}$ of washing buffer (100 mM potassium phosphate buffer, $\mathrm{pH} 7.0$, containing $0.1 \%$ bacto-peptone). The test tubes were then sonicated in an ultrasonic bath for 7 min and vortexed briefly for 15 s, and 10-fold serial dilutions were plated onto LB selective agar plates. The number of colonies was calculated and the epiphytic bacterial sizes were log-transformed before calculating mean population sizes for a given strain.

\section{Expression analysis by qRT-PCR.}

For RNA isolation, wild-type and mutant strains of Pantoea agglomerans pv. gypsophilae were grown on minimal A medium plates for $16 \mathrm{~h}$ at $28^{\circ} \mathrm{C}$. The cells were then scraped from the plates, washed once with sterile water, and suspended in sterile water to an optical density at $600 \mathrm{~nm}$ of 0.5 . RNA was extracted from inoculated cuttings as described above for plant inoculation. MasterPure RNA purification kit (Epicentre Biotechnologies, Madison, WI, U.S.A.) was used to isolate total RNA. Reverse transcription was carried out from $1 \mu \mathrm{g}$ of total RNA pretreated with the Turbo DNA-free (Ambion Inc., Austin, TX, U.S.A) using the Verso cDNA kit (Thermo Scientific, Epsom, U.K.) with random hexamer primers. The resulting cDNAs were subjected to PCR amplification with SYBR green PCR master mix (Applied Biosystems, Warrington, U.K.). The specific primers used in this study were designed by using the AlleleID program (Premier BioSoft International, Palo Alto, CA, U.S.A.) according to the sequence of the corresponding genes. All primers were stored at a concentration of $10 \mu \mathrm{M}$, and $0.3 \mu \mathrm{l}$ of each forward and reverse primer were used per $15-\mu 1$ reaction. The primer pairs as well as the degenerate primers for the internal normalization control gene, gyr $B$, are presented in Table 1 . The expected size of the amplicons was approximately $85 \mathrm{bp}$. Real-time detection was performed with a Rotor-Gene 3000 device (Corbett Research, Sydney, Australia) and the results were analyzed with the Rotor-Gene 6 software. The endogenous control was the $\operatorname{gyr} B$ gene and the calibrator was the wild-type 824-1. A mixture of all cDNAs used in the various treatments was employed as a template for calibration curves designed for each pair of primers. Relative quantification was based on cycle threshold $(\mathrm{Ct})\left(\Delta \Delta \mathrm{C}_{\mathrm{T}}\right)$. The $\Delta \mathrm{Ct}$ value of the sample was determined by subtracting the average $\mathrm{Ct}$ value of the target gene from the average $\mathrm{Ct}$ value of the endogenous control gene. The $\Delta \Delta \mathrm{C}_{\mathrm{T}}$ value was then calculated by subtracting the $\Delta \mathrm{Ct}$ value of the sample from that of the wild type from the same batch. Each experiment was conducted three times and statistical analysis was performed with the Excel software (Microsoft, Seattle).

\section{Confocal images.}

Images of gall sections inoculated with fluorescent bacteria (P. agglomerans pv. gypsophilae strains harboring the plasmid 
pWM1029) were examined under a confocal laser-scanning microscope (model CLSM FluoView 500a; Olympus, Tokyo).

\section{ACKNOWLEDGMENTS}

We thank the Israel Science Foundation for its support under grant number 847/07.

\section{LITERATURE CITED}

Alfano, J. R., and Collmer, A. 2004. Type III secretion system effector proteins: Double agents in bacterial disease and plant defense. Annu. Rev. Phytopathol. 42:385-414.

Ausubel, F. M., Brent, R., Kingston, R. E., Moore, D. D., Seidman, J. G., Smith, J. A., and Struhl, K., eds. 1995. Current Protocols in Molecular Biology. John Wiley \& Sons, Inc., New York.

Barash, I., and Manulis-Sasson, S. 2007. Virulence mechanisms and host specificity of gall-forming Pantoea agglomerans. Trends Microbiol. 15:538-545.

Barnard, A. M. L., Bowden, S. D., Burr, T., Coulthurst, S. J., Monson, R. E., and Salmond, G. P. C. 2007. Quorum sensing, virulence and secondary metabolite production in plant soft-rotting bacteria. Phil. Trans. R. Soc. B. 362:1165-1183.

Brandl, M. T., and Lindow, S. E. 1996. Cloning and characterization of a locus encoding an indolepyruvate decarboxylase involved in indole-3acetic acid synthesis in Erwinia herbicola. Appl. Environ. Microbiol. 62:4121-4128.

Brandl, M. T., and Lindow, S. E. 1998. Contribution of indole-3-acetic acid production to the epiphytic fitness of Erwinia herbicola. Appl. Environ. Microbiol. 64:3256-3263.

Brencic, A., and Winans, S. C. 2005. Detection of and response to signals involved in host-microbe interactions by plant-associated bacteria. Microbiol. Mol. Biol. Rev. 69:155-194.

Broek, A. V., Lambrecht, M., Eggermont, K., and Vanderleyden, J. 1999. Auxin upregulate expression of the indole-3-pyruvate decarboxilase gene in Azospirillum brazilense. J. Bacteriol. 181:1338-1342.

Broek, A. V., Gysegom, P., Ona, O., Hendrickx, N., Prinsen, E., van Impe, J., and Vanderleyden, J. 2005. Transcriptional analysis of the Azospirillum brasilense indole-3-pyruvate decarboxilase gene and identification of a cis-acting sequence involved in auxin responsive expression. Mol. Plant-Microbe Interact. 18:311-323.

Buchanan, B. B., Gruissem, W., and Jones, R. L. 2000. Biochemistry and Molecular Biology of Plants. American Society of Plant Physiology, Rockville, MD, U.S.A.

Burrowes, E., Baysse, C., Adams, C., and O'Gara, F. 2006. Influence of the regulatory protein RsmA on cellular functions in Pseudomonas aeruginosa PAO1, as revealed by transcriptome analysis. Microbiology 152:405-418.

Chalupowicz, L., Manulis-Sasson, M., Itkin, M., Sacher, A., Sessa, G., and Barash, I. 2008. Quorum sensing system affects gall development incited by Pantoea agglomerans pv. gypsophilae. Mol. Plant-Microbe Interact. 21:1094-1105.

Clark, E., Manulis, S., Ophir, Y., Barash, I., and Gafni, Y. 1993. Cloning and characterization of $i a a M$ and $i a a H$ from Erwinia herbicola pathovar gypsophilae. Phytopathology 83:234-240.

Cooley, M., Miller, W., and Mandrell, R. 2003. Colonization of Arabidopsis thaliana with Salmonella enterica and enterohemorrhagic Escherichia coli $\mathrm{O} 157: \mathrm{H} 7$ and competition by Enterobacter asburiae. Appl Environ. Microbiol. 69:4915-4926.

Hirano, S. S., Charkowski, A., Collmer, A., Willis, D. K., and Upper, C. D. 1999. Role of the Hrp type III protein secretion system in growth of Pseudomonas syringae B728a on host plant in the field. Proc. Natl. Acad. Sci. U.S.A. 96:9851-9856.

Koutsoudis, M. D., Tsaltas, D., Minogue, T. D., and von Bodman, S. 2006. Quorum-sensing regulation governs bacterial adhesion, biofilm development and host colonization in Pantoea stewartii subspecies stewartii. Proc. Natl. Acad. Sci. U.S.A. 103:5983-5988

Lapouge, K., Schubert, M., Allain, F. H.-T., and Haas, D. 2008. Gac/Rsm signal transduction pathway of gamma-protobacteria: from RNA recognition to regulation of social behavior. Mol. Microbiol. 67:241-253.

Lichter, A., Barash, I., Valinsky, L., and Manulis, S. 1995. The genes involved in cytokinin biosynthesis in Erwinia herbicola pv. gypsophilae: characterization and role in gall formation. J. Bacteriol. 177:4457-4465.

Lindgren, P. B. 1997. The role of $h r p$ genes during plant-bacterial interactions. Annu. Rev. Phytopathol. 35:129-152.
Lindow, S. E. 1993. Novel method for identifying bacterial mutants with reduced epiphytic fitness. Appl. Environ. Microbiol. 59:1586-1592.

Lindow, S. E., and Brandl, M. 2003. Microbiology of the phyllosphere. Appl. Environ. Microbiol. 69:1875-1883.

Ma, W., Cui, Y., Liu, Y., Korsi Dumenyo, C., Mukherjee, A., and Chatterjee, A. K. 2001. Molecular characterization of global regulatory RNA species that control pathogenicity factors in Erwinia amylovora and Erwinia herbicola pv. gypsophilae. J. Bacteriol. 183:1870-1880.

Manulis, M., and Barash, I. (2003) The molecular basis for transformation of an epiphyte into a gall-forming pathogen as exemplified by Erwinia herbicola pv. gypsophilae. Pages 19-52 in: Plant-Microbe Interactions. Vol. 6. G. Stacey and N. Keen, eds. American Phytopathological Society, St. Paul, MN, U.S.A.

Manulis, S., Valinsky, L., Gafni, Y., and Hershenhorn, J. 1991. Indole-3acetic acid biosynthetic pathways in Erwinia herbicola in relation to pathogenicity on Gypsophila paniculata. Physiol. Mol. Plant Pathol. 39:161-171.

Manulis, S., Haviv-Chesner, A., Brandl, M. T., Lindow, S. E., and Barash, I. 1998. Differential involvement of indole-3-acetic acid biosynthetic pathways in pathogenicity and epiphytic fitness of Erwinia herbicola pv. gypsophilae. Mol. Plant-Microbe Interact. 11:634-642.

Mole, B. M., Baltrus, D. A., Dangl, J. L., and Grant, S. R. 2007. Global virulence regulation networks in phytopathogenic bacteria. Trends Microbiol. 15:363-371.

Monier, J.-M., and Lindow, S. E. 2003. Differential survival of solitary and aggregated bacterial cells promotes aggregate formation of leaf surfaces. Proc. Natl. Acad. Sci. U.S.A. 100:15977-15982.

Mor, H., Manulis, S., Zuc, M., Nizan, R., Coplin, D. L., and Barash, I. 2001. Genetic organization of the hrp gene cluster and dspAE/BF operon in Erwinia herbicola pv. gypsophilae. Mol. Plant-Microbe Interact. 14:431-436.

Morris, R. O. 1986. Genes specifying auxin and cytokinin biosynthesis in phytopathogens. Annu. Rev. Plant Physiol. 37:509-538.

Nissan, G., Manulis, S., Weinthal, D., Sessa, G., and Barash, I. 2005. Analysis of promoters recognized by $\mathrm{HrpL}$, an alternative sigma-factor protein from Pantoea agglomerans pv. gypsophilae. Mol. PlantMicrobe Interact. 18:634-643.

Nizan, R., Barash, I., Valinsky, L., Lichter, A., and Manulis, S. 1997. The presence of $h r p$ genes on the pathogenicity-associated plasmid of the tumorigenic bacterium Erwinia herbicola pv. gypsophilae. Mol. PlantMicrobe Interact. 10:677-682.

Nizan-Koren, R., Manulis, S., Mor, H., Iraki, N. M., and Barash, I. 2003. The regulatory cascade that activates the Hrp regulon in Erwinia herbicola pv. gypsophilae. Mol. Plant-Microbe Interact. 15:I249-260.

Pessi, G., Williams, F., Hindle, Z., Heurlier, K., Holden, M.T., Camara, M., Haas, D., and Williams, P. 2001. The global post-transcriptiona regulator RsmA modulates production of virulence determinants and $\mathrm{N}$ acylhomoserine lactone in Pseudomonas aeruginosa. J. Bacteriol. 183:6676-6683.

Quinones, B., Dulla, G., and Lindow, S. E. 2005. Quorum sensing regulates exopolysaccharide production, motility and virulence in Pseudomonas syringae. Mol. Plant-Microbe Interact. 18:682-693.

Sambrook, J., Fritsch, E. F., and Maniatis, T. 1989. Molecular Cloning: A Laboratory Manual. Cold Spring Harbor Laboratory Press, Cold Spring Harbor, NY, U.S.A

Spaepen, S., Vanderleyden, J., and Remans, R. 2007. Indole-3-acetic acid in microbial and microorganism-plant signaling. FEMS (Fed. Eur. Microbiol. Soc.) Microbiol. Rev. 31:425-448.

Thomson, N. R., Crow, M. A., McGowan, S. J., Sebaihia, M., and Salmond, G. P. 2000. Biosynthesis of carbapenem antibiotic and prodigiosin pigment in Serratia is under quorum sensing control. Mol. Microbiol. 26:539-556.

Valinsky, L., Barash, I., Chalupowicz, L., Ezra, D., and Manulis, S. 2002. Regulation of $h s v G$, a host-specific virulence gene from Erwinia herbicola pv. gypsophilae. Physiol. Mol. Plant Pathol. 60:19-29.

von Bodman, S. B., Bauer, W. D., and Coplin, D. L. 2003. Quorum sensing in plant-pathogenic bacteria. Annu. Rev. Phytopathol. 41:455-482.

von Bodman, S. B., Willey, J.M., and Diggle, S.P. 2008. Meeting review, cell-cell communication in bacteria: united we stand. J. Bacteriol. 190:4377-4391.

Whiteley, M., and Greenberg, E. P. 2001. Promoter specificity elements in Pseudomonas aeruginosa quorum-sensing controlled genes. J. Bacteriol. 183:5529-5534.

Yang, S. F., Zhang, Q., Guo, J., Charkowski, A. O., Glick, B. R., Ibekwe, A. M., and Cooksey, D. A. 2007. Global effect of indole-3-acetic acid (IAA) biosynthesis on multiple virulence factors of Erwinia chrysanthemi 3937. Appl. Environ. Microbiol. 73:1079-1088. 